\title{
Using Bosarang in Enhancing Students' Interest and Creativity on Learning Descriptive Text
}

\author{
$1^{\text {st }}$ Ratna Dwiyaning Raharjanti \\ University of Tidar \\ Magelang, Indonesia \\ Ratnadr.raharjanti@gmail.com
}

\author{
$2^{\text {nd }}$ Damayanti \\ University of Tidar \\ Magelang, Indonesia \\ nenisadamay@gmail.com
}

\author{
$3^{\text {rd }}$ Ayutya Khoirul Mar'ah \\ University of Tidar \\ Magelang, Indonesia \\ ayutyakhoir@yahoo.co.id
}

\begin{abstract}
It is going to be difficult to teach English in a school which has high cultured of Javanese and Islam. Besides, the school is located in a village which is far enough from the center of the city. Therefore, the students could not have enough facilities that may support their learning process. It must be realized that their interest to learn English is still under expectations. They considered English as a difficult subject so they do not like it. Then, how will they compete with billion people after they graduate? Nowadays there are many children and high school students who have excellent English skill. But, what about students in the village who are absolutely need much more support to study? The success of education could not be seen only from a certain side. The researchers try to encourage the students in MTs Ma'arif Kaliangkrik Magelang (Junior High School age level) to like English by giving an interesting way to learn descriptive text. It might be straightforward for junior high school age level, but it becomes very complicated for the students there. The researchers introduced BOSARANG (kind of puzzle of arranging people's body) to make the learning process easier. The purpose of this study is to prove that the use of Bosarang increases students' creativity in making descriptive text. This paper uses quasi experimental research which uses pre-test and post-test to compare the result. Based on the research, it shows that Bosarang totally increases students' creativity.
\end{abstract}

Keywords : Bosarang, teaching method, students' creativity, teaching English, descriptive text.

\section{INTRODUCTION}

English becomes one of the subjects in Indonesia from elementary school up to senior high school. It is a subject based on curriculum based competence. Curriculum based on competence has new terms that mean knowledge, skill and values which are reflected in behaviour. Curriculum based on competence itself means kind of education standard program which encourage students to be competence in what they learn.

In learning English, it is not enough when the students only learn about speaking. They also need to learn about writing. In this term, writing is applied in producing some kinds of text, such as narrative, report, recount, exposition, descriptive, etc. In producing text, there will be many difficulties whether it is about vocabulary or how to develop the idea.

The focus of this study is proving that the use of Bosarang is effective and gives a good result in learning descriptive text. It can be said that not all students in a group like English since it is not their mother tongue. They may be good in other subject but not in English. Teacher cannot blame the students when they do not get a good result in English course. It must be teacher's responsible to find a new way which can make the students encouraged.

It can be said that a group will be more conducive and effective when it has informal and relaxed classroom [1]. Therefore, the students will not feel underpressure while studying a difficult material. The term of active learning has been very popular nowadays, especially to make the students like in the informal and relaxed classroom. So, the use of Bosarang belongs to active learning activity which the students can be more enthusiastic and they feel free to express their ideas.

\section{REVIEW OF LITERATURE}

\section{Teaching method}

As a future teacher, it is important to know about teaching method. It can be said that teaching is delivering knowledge from the teacher to the students. Teaching is like the instrument of art that consists of formula, recipe and algorhytm which needs improvisation and spontaneity. So it can be concluded that teaching method is the way how the teacher teaches.

\section{Active learning}

Active learning is kind of teaching method that encourages students to be active in term of finding the main idea of the material, solving the problem or applying what they have learnt in their real life. [2]

\section{Creativity}

Creativity can be said as how the students think about something new and the way they solve the problem. According to [3], creative student has some characteristics such as having a big interest in something and always encouraged to try something new. In this term, the use of bosarang is hoped can increase students' creativity. 
Bosarang is kind of puzzle. There are some research which proved that using puzzle on the learning process is effective, fun and increasing students' creativity. A research with the title "Efektifitas Metode Permainan Puzzle terhadap Kemampuan Menulis Surat Dinas oleh Siswa Kelas VIII SMP Negeri 5 Medan Tahun Pembelajaran 2013/2014" proved that experiment group which used puzzle get the average value 86,58. Meanwhile, the control group which did not use puzzle, only got average value 76,27 .

That research result proves that the use of puzzle on learning process really give big influence to the result. Therefore, Bosarang which is like puzzle can be said that it is more interesting than the other puzzle since the students can choose the pieces of the people's body by themselves to make a puzzle. It will bring the group become interesting when the students consider English as a difficult lesson.

\section{Method}

\section{Research design}

This research focused on the students' achievements both the control and experiment group it shows how beneficial Bosarang in supporting students to learn descriptive text. This research used experimental research to collect the data. So, the researchers conducted pre-test and post-test to know and compare the result.

TABLE I. TABLE STYLES

\begin{tabular}{|c|c|c|c|c|}
\hline \multirow{2}{*}{$\begin{array}{c}\text { GRO } \\
\text { UP }\end{array}$} & \multicolumn{3}{|c|}{ Table Column Head } & \multirow[b]{2}{*}{ Post-test } \\
\hline & pretest & $\begin{array}{l}\text { Lecturi } \\
\quad \text { ng } 1\end{array}$ & $\begin{array}{c}\text { Lecturin } \\
\quad \text { g } 2\end{array}$ & \\
\hline A & $\mathrm{P}_{1}$ & $\mathrm{D}_{1}$ & $\mathrm{D}_{2}$ & $\mathrm{P}_{2}$ \\
\hline B & $\mathrm{P}_{1}$ & $\mathrm{D}_{1}$ & $\mathrm{D}_{2}$ & $\mathrm{P}_{2}$ \\
\hline
\end{tabular}

$\begin{array}{ll}\text { A } & \text { : Group using Bosarang } \\ \text { B } & \text { : Group without Bosarang } \\ \text { P1 } & \text { : Pre-test } \\ \text { D1 } & \text { : Lecturing 1 } \\ \text { D2 } & \text { : Lecturing 2 } \\ \text { P2 } & \text { : Post-test }\end{array}$

\section{Population and sample}

Population in this research was the $8^{\text {th }}$ grade students of MTs Ma'arif Kaliangkrik 2017/2018. There were 81 students that were divided into 3 classes which each group consists of 24-30 students.

Meanwhile for the sample, the researchers took 2 groups to be observed. There were 50 students from those 2 groups. Those 2 groups would be the experiment group and the rest would be the control group.

\section{Data collection}

In collecting the data, the researchers used pre-test and posttest which both of them were needed to emphasize the information about the influence of using Bosarang on learning descriptive text. In pre-test, the students were asked to make descriptive text about people based on their knowledge before the researchers gave some explanations. Then the next two meeting, the students were given material about descriptive text. The first group was not using Bosarang and the second was. For the last meeting, students were asked again to make descriptive text about people after they got explanation on the previous meeting.

Data analysis
The researchers analyzed the obtained data by comparative technique. It meant that there were two observation groups, the first one was using Bosarang (experimental group) and the rest was not (control group). The researchers tried to analyze the result, how far the use of Bosarang on learning descriptive text could influence students' creativity in making descriptive text and how significant the difference between those two groups.

$$
\mathrm{T}_{\mathrm{o}}=\frac{m a-m b}{\left(\frac{x a+x b}{n a+n b-2}\right)\left(\frac{1}{n a}+\frac{1}{n b}\right)}
$$

T : total score

Ma : mean value (group A)

$\mathrm{Mb} \quad$ : mean value (group B)

$\sum$ xa : variety of group $A$

$\sum \mathrm{xb} \quad$ : variety of group B

$\mathrm{Na}:$ : the number of students in group A

$\mathrm{Nb}$ : the number of students in group B

Based on Brown's concept (2004:287), the result of the test can be classified into 5 categories :

$\begin{array}{ll}85-100 & : \text { excellent } \\ 70-85 & : \text { good } \\ 60-69 & : \text { enough } \\ 50-59 & : \text { poor } \\ \text { Less than 50 } & \text { : very poor }\end{array}$

\section{FINDINGS AND DISCUSSION}

Based on the focus of this research about how effective the use of Bosarang in learning descriptive text. In analyzing the data, the researchers used comparative technique. Here was the data that had been collected by the researchers:

\section{Experiment group}

\section{Pre-test}

Pre-test was conducted on May $30^{\text {th }}$ 2018. The group was started at 8.00 up to 11.00 a.m, but they only had 60 minutes to do pre-test. They had 30 minutes for breaktime and continued by discussion activity and ice breaking. It was begun by introducing by the researchers. Then, the students were asked to make a descriptive text about people. They could choose their own topic such as describing their teacher, idol, parents, friend and many more. Based on the researchers' observation, the students were still confused how to make descriptive text although they had been taught by their teacher. They got difficulties in choosing the words, constructing the sentences, and developing the ideas. The result of their pre-test had not been good enough. The average value of the experiment group was 64.2.

\section{Meeting 1 (without using Bosarang)}

The next day, on May 31st 2018 the researchers gave the students more explanation about descriptive text. Like the previous meeting, the group was started at 8.00 up to 11.00 a.m, They were explained about the definition, the generic structure, the function, the tenses that would be used, how to choose the words / diction, and how to develop the idea. The researchers explained them by giving explanations and gave a chance for the students to ask questions. The students were enjoying the group since the researchers also gave an ice breaking to avoid them to be bored because of the difficult lesson. Based on the observation, it could be analyzed that English became a lesson that was not really interesting for the students of MTs Ma'arif Kaliangkrik.

Meeting 2 (using Bosarang) 

about descriptive again. It was like the previous meeting, but the researchers tried to apply the use of Bosarang in the experiment group. First, the researchers lead a warming up activity to make the students encouraged. Then the researchers continued the material by explaining them about descriptive text but they used Bosarang. The researchers gave an example how to use Bosarang then distributed it to the students that had been divided into group of two. The students looked like very happy and enjoy the group. They arranged the puzzle as they want to arrange. After they finished arranging the puzzle, the researchers asked some of the students to present their work in front of the group. Each group was able to make the different puzzle with the others. So, their work became more various. Based on the observation, it can be seen that the second meeting which used Bosarang was more fun and the students became more active.

\section{Post-test}

After the students were given explanation in two meetings, on the last day, June $6^{\text {th }} 2018$ the researchers asked the students to make a descriptive text about people as the posttest. The instructions were same with their pre-test. On the post-test session, the students were doing it better than their pre-test. They were more confident in wrote their text and they were able to create a long paragraph. It meant that they had been able to develop the idea and got more new vocabularies. For the experiment group, the average value of their post-test was 77.4. It was much better than the pre-test. So, it can be concluded that Bosarang really gave big impacts for developing students' ability and creativity.

\section{Control group}

\section{Pre-test}

Like the experiment group, the schedule of the first day was pre-test. First of all, the researchers introduced themself in the control group. Then, the students were asked to make a descriptive text without any explanation from the researchers. They only had 60 minutes to do pre-test. Then, they had a break time and continued by sharing activity with the researchers. Based on the observation, the students still got difficulties in creating descriptive text especially in developing the idea, choosing the words / diction, constructing the sentences and many more. The pre-test result of control group had not been good yet and they were not better than the experiment group. The average value was 64.

\section{Meeting 1 (without Bosarang)}

The next day, the researchers gave more explanation to the students about descriptive text. The group was started at 8.00 up to 11.00 a.m with 30 minutes break time at 9.009.30 a.m. They were explained about descriptive text, such as the definition, the generic structure, the function, the tenses that would be used, how to choose the words / diction, and how to develop the idea. The researchers explained them by giving explanations and gave a chance for the students to ask questions. The students were enjoying the group since the researchers also gave an ice breaking to avoid them to be bored because of the difficult lesson. Based on the observation, it could be analyzed that English most of them do not really like English since it was difficult.

\section{Meeting 2 (without Bosarang)}

The next day, the researchers continued explaining the material. The basic concept of descriptive text had been explained on the previous day. So, in the meeting 2 (without Bosarang), the researchers only added some explanations like giving new vocabularies, tenses, etc. Therefore, the students had more chances to ask questions that they had not understood. They also asked for ice breaking since they began to be bored with the material. Based on the observation, it could be analyzed that the students had been more understood about what descriptive text is and how to produce a good text.

\section{Post-test}

Post-test session was the last day of this research. After got explanation about descriptive text in the two previous days, the students were asked to make a descriptive text again. In the control group, they were asked to write descriptive text about favorite teacher. They had 60 minutes to make it, started from 8.00 - 9.00 a.m. After that, the students and the researchers had a small discussion whether about the material or just shared about the students' difficulties in learning in order to make the them became closer with the researchers who acted as their teachers. A deep teacherstudent relationship meant they had self-belonging which was important for students' success in learning [4]. That was why the researchers tried to be closer with the students. Control group was a group that was observed without the use of Bosarang. So, their post-test result showed that the experiment group was better. The post-test result of control group was increasing but it was still under the experiment group. The average value of control group was 69.2 .

Based on the research, researchers can collect the data in this table:

TABLE II. COLLECTED DATA

\begin{tabular}{|r|l|l|l|}
\hline \multirow{2}{*}{ No. } & \multicolumn{3}{|c|}{ Table Column Head } \\
\cline { 2 - 4 } & Table column subhead & $\begin{array}{l}\text { Experimen } \\
\text { tgroup (a) }\end{array}$ & $\begin{array}{c}\text { Control } \\
\text { group } \\
\text { (b) }\end{array}$ \\
\hline 1. & Number of student (n) & 25 & 25 \\
\hline 2. & $\begin{array}{l}\text { Pre-test average score } \\
\text { (m) }\end{array}$ & 64.2 & 64 \\
\hline 3. & Pre-test varian (x) & 418.6 & 2216 \\
\hline 4. & $\begin{array}{l}\text { Post test average score } \\
\text { (m) }\end{array}$ & 77.4 & 69.2 \\
\hline 5. & Post-test varian (x) & 236.2 & 2312 \\
\hline
\end{tabular}

A. PRETEST

$$
\begin{aligned}
\mathrm{T}_{\mathrm{o}} & =\frac{m a-m b}{\left(\frac{x a+x b}{n a+n b-2}\right)\left(\frac{1}{n a}+\frac{1}{n b}\right)} \\
\mathrm{T}_{0} & =\frac{64,2-64}{\left(\frac{418,6+2516}{25+25-2}\right)\left(\frac{1}{25}+\frac{1}{25}\right)} \\
& =\frac{0,6}{\left(\frac{26345}{48}\right)\left(\frac{2}{05}\right)} \\
& =0.137
\end{aligned}
$$

After getting the significant result of pre-test, then it is checked to t-table with $95 \%$ level significance. There is significant difference between experiment and control group if the t-test result is more than t-table. In the t-table with degree of freedom $25-2=48$ is 1.708 , while the t-test result is 0.137 . It shows that t-test is less than t-table. ( $0.137<$ 1,708 ). It means that there is no significant difference between two groups.

$$
\begin{aligned}
& \text { A. POST TEST } \\
& \mathrm{T}_{\mathrm{o}}=\frac{m a-m b}{\left(\frac{x a+x b}{n a+n b-a}\right)\left(\frac{1}{n a}+\frac{1}{n b}\right)}
\end{aligned}
$$


${ }^{0}=\frac{\left(\frac{286,2+2812}{25+25-2}\right)\left(\frac{1}{35}+\frac{1}{25}\right)}{7.45}$

7,4

\section{$\left.=\frac{7548}{48}\right)\left(\frac{3}{35}\right)$}

$=1,742$

After getting the significant result of pre-test, then it is checked to t-table with $95 \%$ level significance. There is significant difference between experiment and control group if the t-test result is more than t-table. In the t-table with degree of freedom $25-2=48$ is 1.708 , while the t-test result is 1.742. It shows that t-test is less than t-table. $(1.742>1.708)$ that means there is significant differences between two groups.

\section{CONCLUSION}

It was going to be difficult to teach English as foreign language, especially in the school which was located far enough with the center of the city since they did not have enough facility. Based on the research that had been done, the experiment group showed a better result than the control group. It meant that the use of Bosarang really gave a positive impact to the learning process. It could increase students' creativity and made the group become more active. Bosarang could be considered by English teachers as the media to encourage the students in learning descriptive text.
This research had proved that it is an effective way to teach since the students could get a better test result and they really enjoyed the group. It was still related to Simran Khurana's theory [5] that a great teacher was not just delivering material but also inspiring and encouraging the students in term of learning.

\section{References}

[1] Sukarno, "Cross cultural understanding: a literary based approach”, Surabaya: FBS UNESA PRESS, 2014.

[2] Zaini, "Strategi Pembelajaran Aktif", Yogyakarta: CTSDIAIN Sunan Kalijaga, 2002.

[3] Munandar, S.C. Utami, "Mengembangkan Bakat dan Kreativitas Anak Sekolah", Jakarta: PT. Gramedia Widiasarana, 1992.

[4] Gablinske, Patricia Brady, "A case study and teacher relationships and the effect on students' learning", Open access disertations. Paper 266, 2014. Retrieved from http://digitalcommons.uri.edu/oa_diss 266

[5] Khurana, Simran, "Quotes about good teachers: good teachers are rare breed", 2017. Retrieved from http://quotations.about.com/bio/simran-khurana9119.html 